\title{
Analisis Kinerja Keuangan Koperasi pada Kospin Jasa Sebelum dan Sesudah Penerapan sistem Online
}

\author{
H. Muhammad Arif Kurniawan, SE., MM ${ }^{(1)}$ \\ Politeknik Pusmanu Pekalongan \\ m_arif_18686@yahoo.co.id
}

Aria Mulyapradana., S.Psi., MA ${ }^{(2)}$

Politeknik Pusmanu Pekalongan

ariamulyapradana@gmail.com

\begin{abstract}
Abstraksi Penelitian ini bertujuan untuk menguji ada tidaknya perbedaan OHC, BOPO, ROA, dan LDR pada Kospin Jasa sebelum penerapan online dan sesudah penerapan online. Populasi penelitian ini adalah Kospin Jasa sejumlah 30 kantor cabang. Pemilihan sampel dilakukan dengan metode purpose sampling dengan menetapkan kriteria sampel. Kriteria saham-saham yang akan dilakukan penelitian untuk dijadikan sampel penelitian adalah sebagai berikut: Kospin Jasa yang mempunyai OHC dan ROA positif selama periode amatan. Dari 30 Kospin Jasa diperoleh sampel sebanyak sebanyak 22 Kospin Jasa. Penelitian diuji dengan menggunakan Uji beda paired sample t-test. Hasil penelitian ini menunjukkan bahwa adanya perbedaan yang signifikan OHC, BOPO, ROA, dan LDR pada Kospin Jasa sebelum penerapan online dan sesudah penerapan online
\end{abstract}

Keyword Analisa, Keuangan, Koperasi, Kospin Jasa dan Sistem Online

\section{PENDAHULUAN}

Tumbuhnya pelbagai macam Koperasi Simpan Pinjam (KSP/Kospin) di peta Perkoperasian Simpan Pinjam Indonesia telah meningkatkan iklim kompetensi yang semakin tajam dibidang pelayanan jasa Perkoperasian Simpan Pinjam. Hal ini menjadi suatu tantangan yang harus dihadapi dan ditangani oleh suatu KSP. Adanya KSP-KSP yang berdiri di Indonesia, masyarakat akan dihadapkan pada pilihan akan produk yang ditawarkan oleh KSP-KSP yang sekarang ini bermunculan. Bagi masyarakat atau anggota dan calon anggota, pelayanan jasa 
Simpan Pinjam yang bermutu sangat penting, karena persaingan antar KSP dipengaruhi oleh kemampuan KSP dalam memberikan pelayanan terbaik yang bermutu dibandingkan pesaingnya. Tekanan persaingan dan tuntutan kualitas layanan bagi anggota dan calon anggota, akibat jenis transaksi beragam, frekuensi transaksi yang tinggi setiap hari, membuat efektivitas KSP menjadi meningkat. Hal ini yang mendorong KSP untuk melakukan perubahan dibagian operasionalnya yang terkait dengan semua proses transaksi Perkoperasian Simpan Pinjam dengan implementasi teknologi informasi. Dengan implementasi teknologi informasi, KSP dapat memberikan pelayanan jasa Perkoperasian Simpan Pinjam lebih cepat dan akurat. Selain itu, memudahkan bagi anggota dan calon anggota dalam melakukan transaksi Perkoperasian Simpan Pinjam (Zaky Arslan Djunaid, 2008).

Koperasi Simpan Pinjam "JASA" atau lebih dikenal dengan Kospin Jasa, merupakan salah satu Koperasi Simpan Pinjam yang telah mengalami transformasi dalam implementasi teknologi informasi. Sebagai Koperasi Simpan Pinjam dengan jangkauan pelayanan se-Nusantara dari Lampung, Pulau Jawa hingga Pulau Bali, Kospin Jasa terus meningkatkan mutu pelayanan anggota dan calon anggotanya. Peningkatan mutu pelayanan tersebut tidak hanya sebatas pengertian personil, individu, serta interaksi antara perseorangan dengan anggota dan calon anggota, namun juga peningkatan terhadap sarana dan prasarana yang memadai utamanya perangkat teknologi operasionalnya. Dikarenakan jangkauan pelayanan se-Nusantara dari Lampung, Pulau Jawa sampai Pulau Bali, maka Koperasi Simpan Pinjam "JASA" mengimplementasikan sistem teknologi informasi dan komunikasi, yaitu online sistem yang diberinama "SysOn" Kospin Jasa (Sistem Online Koperasi Simpan Pinjam "JASA") sebagai jawaban atas permasalahan yang dihadapi, dalam jangka panjang, dapat meningkatkan daya saingnya dan kualitas pelayanan kepada anggota dan calon anggotanya serta kinerja Kospin Jasa (Zakky Arslan Djunaid, 2008).

Koperasi Simpan Pinjam "JASA" telah mengimplementasikan sistem online disemua kantor layanan Kospin Jasa yang ada pada penghujung tahun 2008. Secara keseluruhan otomatisasi dengan sistem online memfasilitasi aktivitasaktivitas Kospin Jasa sebagai berikut:

1. Fungsi Operasi, yaitu memfasilitasi Kospin Jasa dalam bertransaksi dengan anggota dan calon anggota, meliputi Simpanan maupun Pinjaman dan jasajasa lainnya.

2. Fungsi Akuntansi, yaitu memfasilitasi pencatatan, peringkasan dan pelaporan serta transaksi keuangan Kospin Jasa. Pelaksanaan fungsi Akuntansi Kospin Jasa yang kompleks, dari pencatatan sampai pelaporan, sepenuhnya dapat difasilitasi oleh teknologi komputer termasuk pembuatan laporan siap cetak.

3. Fungsi Komunikasi data, yaitu memfasilitasi komunikasi data antar unit kerja dalam cabang yang sama, cabang dengan cabang pembantu, kas pembantu, antar cabang, cabang dengan kantor pusat maupun sebaliknya.

Dengan adanya SysOn ini setiap kantor layanan Kospin Jasa dapat melakukan penukaran data atau informasi yang dibutuhkan dengan mudah. Selain itu dengan adanya SysOn, setiap anggota dan calon anggota tidak perlu lagi merasa kesulitan 
jika berada diluar daerah untuk melakukan transaksi setoran ataupun penarikan, karena bisa bertransaksi disemua kantor layanan Kospin Jasa dimana saja, selain itu juga anggota dan calon anggota tidak harus menunggu lama lagi dalam melakukan transaksi seperti mengirim atau menerima uang, serta dengan adanya SysOn banyak perusahaan-perusahaan yang ingin bergabung memanfaatkan dalam hal kerjasama yang saling menguntungkan dengan Kospin Jasa, seperti PT. Telkom dalam rangka pembayaran kiriman uang para Tenaga Kerja Indonesia diluar negeri kepada keluarganya di Indonesia, dengan PT. Pos Indonesia untuk transaksi penyetoran tabungan, Simpanan dan Pinjaman di Kopsin Jasa melalui Kantor Pos di seluruh indonesia, dengan PT. Bank Permata untuk transaksi melalui Kartu Debit Visa Elektron Kospin Jasa, anggota dan calon anggota dapat bertransaksi diseluruh dunia baik dalam negeri maupun luar negeri sehingga mengikis kendala waktu transaksi dan memberikan efektifitas transaksi (Andy Arslan Djunaid, 2011). Terkait dengan implementasi SysOn untuk mengetahui kinerja Kospin Jasa dapat dilihat dari data laporan perkembangan Kospin Jasa

Secara umum kinerja Kospin Jasa cenderung meningkat dari tahun ke tahun, terutama dari sisi total asset, pendapatan, laba dan dana masyarakat (Simpanan dan Tabungan). Demikian pula, jika dilihat dari rasio BOPO, juga cenderung ada perbaikan dari tahun ke tahun. Dalam sebuah neraca Koperasi Simpan Pinjam, total asset terdiri aktiva produktif (earning assets/EA) dan aktiva non produktif (non earning assets/NEA). Aktiva produktif adalah aktiva yang menghasilkan pendapatan (revenue), meliputi Pinjaman yang diberikan, dan investasi lainnya. Adapun aktiva non produktif, meliputi gedung, peralatan dan perlengkapan lainnya. Pada bisnis Koperasi Simpan Pinjam, kenaikan asset produktif umumnya diikuti dengan kenaikan pendapatan atau SHU. Yang perlu dipahami, bahwa kenaikan asset produktif, terutama dalam bentuk pemberikan pinjaman, hanya dapat dilakukan jika Koperasi Simpan Pinjam mampu menghimpun dana masyarakat (simpanan dan tabungan). Peningkatan ini, kemungkinan disebabkan perbaikan kualitas layanan kepada anggota dan calon anggota melalui implementasi teknologi informasi, sehingga anggota dan calon anggota tetap menggunakan Kospin Jasa sebagai mitranya atau ada tambahan dari anggota dan calon anggota baru. Lebih lanjut, indikator perbaikan kinerja Kospin Jasa, tercermin dari peningkatan SHU dan rasio BOPO. Sejak penggunaan teknologi informasi online sistem akhir tahun 2008, terjadinya perbaikan kinerja tersebut, memang masih belum dapat dipastikan, karena faktor implementasi teknologi online sistem di Kospin Jasa. Akan tetapi, dari data tersebut dapat diindikasikan bahwa implementasi teknologi online sistem antar kantor layanan memberikan dampak positif terhadap kinerja Kospin Jasa, terutama dari sisi SHU dan efisiensi biaya.

Beberapa pernyataan yang ditemukan oleh peneliti pada kegiatan pra survey pada beberapa kantor layanan Kospin Jasa, terdapatnya suatu fakta dihapusnya beberapa biaya tunjangan, seperti tunjangan Kasir atau Teller, penghapusan 1 (satu) karyawan 1 (satu) bagian, misal sebelum online sistem bagian CSO (Costumer Service Officer) 1 (satu) karyawan, bagian Administrasi Simpanan 1 (satu) karyawan, setelah online sistem bagian CSO dan Administrasi Simpanan 
menjadi 1(satu) karyawan, sehingga efisiensi biaya tenaga kerja dan menambahan beban pekerjaan bagi karyawan, terlebih setelah adanya online sistem setiap karyawan harus mencapai target yang dibebankan masing-masing karyawan, tentunya juga berakibat pada kinerja Kospin Jasa secara keseluruhan.

Dengan melihat titik persamaan dalam hal tujuan pencapaian kinerja keuangan sebelum dan sesudah online sistem, maka rasio-rasio yang menjadi kesamaan antara keadaan sebelum dan sesudah online sistem pada Kospin Jasa menjadi tujuan akhir dilakukannya online sistem tersebut tentunya mengalami perbaikan seperti dalam rasio-rasio kinerja keuangan yang berkaitan dengan $\mathrm{OHC}$ (overhead cost), BOPO (biaya operasional dan pendapatan operasional), ROA (return on assets), dan LDR (loan to total deposits ratio)

Pasca online sistem bukan berarti masalah selesai, dinamika apresiatif dalam pelaksanaannya selalu dievaluasi dan dikaji ulang, kebijakan yang baik dimaksudkan untuk menciptakan peluang ekonomis yang lebih besar, namun perlunya mencermati sinyalemen seperti yang disampaikan (Mongide, 1997) adalah adanya suatu sistem penggajian yang baik namun ternyata memunculkan masalah menurunnya gaji karyawan, adanya sistem manajemen yang baru dengan tekanan pada efisiensi biaya namun justru yang terjadi pembengkakan biaya maupun justru menjadi hambatan operasional, serta adanya online sistem untuk mendatang kesehatan baru namun justru yang muncul mengumpulkan penyakit baru. Dengan demikian pasca online sistem dengan seluruh dinamikannya menunjukkan perlu kajian dalam suatu penelitian secara mendalam untuk menentukan evaluasi terhadap keberhasilan kinerja keuangan sehingga mencapai seperti yang diharapkan.

Dengan melihat latar belakang keseriusan Kospin Jasa diharapkan pada masa-masa mendatang memiliki kinerja yang lebih baik dengan adanya langkah pengimplementasian Sistem Online Kospin Jasa. Melihat hal tersebut untuk membandingkan pencapaian kinerja sebelum dan sesudah penerapan Sistem Online.

Berdasarkan pada latar belakang permasalahan diatas, maka perumusan masalah adalah : Terjadinya ketidak tentuan perbedaan kinerja keuangan koperasi dilihat dari OHC, BOPO, ROA dan LDR, sebelum penerapan Sistem Online dan sesudah penerapan Sistem Online pada Kospin Jasa.

Mengingat bahwa implementasi Sistem Online adalah merupakan alternatif ekonomis yang telah menjadi pilihan strategis pada Kospin Jasa, maka penelitian ini dilakukan untuk memperoleh jawaban atas pertanyaan penelitian sebagai berikut:

1. Bagaimanakah perbedaan Kinerja Keuangan Kospin Jasa sebelum dan sesudah penerapan Sistem Online dilihat dari aspek OHC?

2. Bagaimanakah perbedaan Kinerja Keuangan Kospin Jasa sebelum dan sesudah penerapan Sistem Online dilihat dari aspek BOPO?

3. Bagaimanakah perbedaan Kinerja Keuangan Kospin Jasa sebelum dan sesudah penerapan Sistem Online dilihat dari aspek ROA?

4. Bagaimanakah perbedaan Kinerja Keuangan Kospin Jasa sebelum dan sesudah penerapan Sistem Online dilihat dari aspek LDR? 


\section{LITERATURE REVIEW}

\subsection{Pengertian Koperasi Simpan Pinjam}

Menurut Undang-undang Republik Indonesia Nomor 25 tahun 1992 tentang Perkoperasian, Koperasi adalah badan usaha yang beranggotakan orang seorang atau badan hukum Koperasi dengan melandaskan kegiatannya berdasarkan prinsip Koperasi sekaligus sebagai gerakan ekonomi rakyat yang berdasar atas asas kekeluargaan. Jadi koperasi bukanlah perkumpulan modal usaha yang mencari keuntungan semata, tetapi koperasi dibentuk untuk memenuhi kebutuhan anggota dengan memberikan harga semurah mungkin dan pelayanan sebaik mungkin.

Undang-undang Dasar 1945 Pasal 33 ayat (1), menjelaskan bahwa bukan kemakmuran orang perseorang yang diutamakan melainkan kemakmuran dan kesejahteraan bersama dan yang sesuai dengan itu adalah Koperasi. Koperasi salah satu sektor kekuatan ekonomi diharapkan menjadi soko guru perekonomian Indonesia, karena koperasi merupakan badan usaha yang sesuai dengan demokrasi ekonomi bangsa Indonesia yaitu dari rakyat, oleh rakyat dan untuk rakyat.

Menurut Peraturan Pemerintah Nomor 9 Tahun 1995 tentang Pelaksanaan Kegiatan Usaha Simpan Pinjam, kegiatan usaha simpan pinjam adalah kegiatan yang dilakukan untuk menghimpun dana dan menyalurkannya melalui kegiatan usaha simpan pinjam dari dan untuk anggota koperasi yang bersangkutan, calon anggota koperasi yang bersangkutan, koperasi lain dan atau anggotanya.

Terdapat dua bentuk Koperasi Simpan Pinjam yang dikembangkan oleh Kementerian Negara Koperasi dan UKM yaitu : (1) Koperasi Simpan Pinjam disebut KSP yang melaksanakan kegiatan usahanya hanya usaha simpan pinjam, dan (2) Unit Simpan Pinjam disebut USP adalah unit usaha yang dibentuk dalam suatu koperasi sebagai bagian dari kegiatan usaha koperasi melakukan kegiatan usaha simpan pinjam (PP No. 9 Thn 1995).

\subsection{Pengertian Sistem Online Kospin Jasa}

Sistem on-line adalah sistem informasi dalam suatu organisasi atau perusahaan yang bersifat langsung dan tanpa adanya proses data entry yang berulang-ulang. Salah satu ciri utama dari sistem data on-line adalah ketiadaannya atau minimnya penggunaan dokumen-dokumen berupa kertas atau lebih sering disebut sebagai Scripless.

Kelebihan sistem data on-line yang langsung dapat dilihat dan dirasakan adalah adanya penghematan dalam hal biaya atau cost, kemudian lebih cepat dan tepatnya aliran dan penerimaan informasi atau data, dan kemudian dapat dirasakan 
bahwa manajemen suatu organisasi atau perusahaan dapat lebih cepat dan tepat dalam hal pengambilan keputusan.

Sistem data on-line dalam prakteknya menggunakan atau ditunjang oleh suatu alat atau piranti lunak. Alat penunjang sistem data on-line ini sering disebut sebagai software. Ada banyak software yang dipakai untuk mengimplementasikan sistem data on-line. Salah satu software yang paling digunakan oleh Kospin Jasa dalam mengimplementasikan sistem data on-line adalah software SysOn. Software $\mathrm{Sys} O n$ inilah yang digunakan oleh Kospin jasa didalam mengimplementasikan sistem data on-linenya.

Di era digital saat ini, transaksi real time online telah menjadi kebutuhan wajib bagi lembaga keuangan khususnya Kospin Jasa yang terdapat lebih dari 95 kantor layanan baik cabang, cabang pembantu maupun kas pembantu.

Sistem Online Kospin Jasa atau lebih dikenal "SysOn" pada Kospin Jasa merupakan Aplikasi terintegrasi dan sesuai dengan PSAK No.27 yang disusun oleh Tim Pedoman Pembukuan dan Teknologi Informasi Kospin Jasa tentang Standar Akuntansi Keuangan Koperasi yang telah diberlakukan sejak tahun 1970an, tetapi sejak akhir tahun 2008 mulai terintegrasikan (online). Sistem ini dibangun sesuai perkembangan teknologi terkini dan fungsionalitas, dikembangkan dengan beragam fitur, fasilitas produk guna memberikan kemudahan transaksi real time online dalam manajemen produk yang tepat bagi setiap anggota maupun calon anggota Kospin Jasa.

Melalui implementasi arsitektur teknologi yang tersentral ini, kebutuhan akan data dan informasi bagi anggota, calon anggota, manajemen, maupun pemangku kepentingan dapat dipenuhi secara cepat dan akurat. Hal ini tentunya harus didukung oleh sumber daya manusia yang kompeten melalui pelatihan dan panduan teknis yang jelas.

SysOn merupakan suatu solusi core Kospin Jasa System bersifat customisable yang dapat disesuaikan dengan kebutuhan Kospin Jasa terutama yang terkait dengan perubahan proses bisnis yang bersumber pada perubahan regulasi, ketentuan, maupun kebijakan lainnya.

SysOn bukan saja mampu membuat Kospin Jasa lebih optimal dan efisien, tetapi juga memberikan add value yang dibutuhkan bagi Kospin Jasa untuk berkembang dan eksis didalam dunia persaingan lembaga keuangan yang ketat. Bahkan dengan Kospin Jasa menerapkan Sistem online banyak pihak yang mengajak kerjasama seperti contoh Kantor Pos dan Telkomsel. Kerjasama ini saling menguntungkan kedua belah pihak, dimana anggota dan calon anggota yang kebetulan kota/kabupatennya belum ada kantor layanan Kospin jasa tidak lagi repot untuk bertransaksi, karena bisa menggunakan jasa layanan Kantor Pos terdekat. Disamping itu pengembangan dari sistem online ini Kospin Jasa telah mengeluarkan Produk Kartu Debit Kospin Jasa. Karena Kospin Jasa bukan lembaga perbankan sehingga tidak dapat berdiri sendiri dalam mengeluarkan atau menggunakan Kartu ATM, maka Kospin Jasa melakukan kerjasama dengan salah satu lembaga perbankan nasional yaitu Permata Bank. 


\subsection{Penilian Kinerja Koperasi Simpan Pinjam}

Kinerja suatu perusahaan adalah seberapa efisien dan efektif sebuah organisasi atau seberapa baik organisasi itu menetapkan dan mencapai tujuan yang memadai. Bagi investor, informasi tentang kinerja tersebut dapat digunakan untuk melihat apakah mereka akan mempertahankan investasi mereka. Kinerja perlu diukur, dievaluasi untuk menentukan sejauh mana keberhasilan perusahaan dalam mencapai tujuan. Dua aspek yang sering digunakan dalam menilai kinerja adalah efisiensi dan efektifitas. Efisiensi menggambarkan hubungan input dan output. Sedangkan efektifitas merupakan gambaran hubungan output pada suatu tujuan tertentu. Pengukuran kinerja adalah kunci dalam infrastruktur organisasi. Istilah tersebut mencakup suatu set kebijakan organisasional, sistem dan praktek yang mengkoordinasikan tindakan serta transfer ini untuk mendukung siklus manajemen. Manajemen menggunakan sistem pengukuran sebagai mekanisme untuk implementasi strategi.

\subsection{Metode-metode pengukuran kinerja Koperasi Simpan Pinjam}

Pengukuran kinerja keuangan perusahaan dipakai oleh manajemen perusahaan dan para stakeholder perusahaan untuk menilai keberhasilan yang telah dicapai oleh perusahaan. Ada beberapa teknik atau beberapa parameter kinerja keuangan yang dipakai oleh manajemen atau para stakeholder tersebut. Secara umum, kinerja keuangan adalah perhitungan yang melibatkan nilai investasi yang dikeluarkan oleh perusahaan dan laba (profit) atau aliran arus kas masuk yang dihasilkan perusahaan setelah adanya investasi tersebut (investasi berupa aktiva operasional).

\subsection{Kerangka Pikir Penelitian}

Semakin besar tingkat resiko perluasan usaha maka semakin besar pula keuntungan yang diharapkan. Tujuan utama dari penelitian ini adalah untuk menganalisis besarnya resiko investasi dan hubungannya dengan tingkat keuntungan pada perluasan usaha yang dilakukan Kospin JASA. Penanam modal selalu menggunakan analisis keuangan untuk mengambil keputusan tentang investasinya. Analisis keuangan menyediakan suatu ukuran bagi manajer tentang jalannya perusahaan dibandingkan dengan prestasinya pada tahun-tahun lalu dan dengan pesaingnya. Ada dua kelompok dasar rasio keuangan yaitu likuiditas dan profitabilitas (rentabilitas). Rasio likuiditas digunakan sebagai petunjuk kemampuan perusahaan untuk memenuhi kewajibannya dalam jangka pendek. Kewajiban ini termasuk setiap hutang lancar hutang jangka panjang yang telah jatuh tempo. Rasio profitabilitas (kemampulabaan) merupakan hasil bersih dari sejumlah besar kebijakan dan keputusan yang diambil oleh manajemen organisasi. 
Rasio kemampulabaan menunjukkan seberapa efektif seluruh perusahaan itu dikelola.

Analisis keuangan dipakai pula untuk merumuskan kondisi. Kondisi adalah rencana yang disatukan menyeluruh dan terpadu yang mengaitkan keunggukan kondisi perusahaan dengan tantangan lingkungan dan yang dirancang untuk memastikan bahwa tujuan utama perusahaan dapat dicapai melalui pelaksanaan yang tepat oleh perusahaan. Daripada memusatkan seluruh waktu pada keadaan sekarang ini, para manajer mulai melihat pentingnya mencoba mengetahui lebih dulu masa depan dan bersiap untuk menghadapinya.

Untuk singkatnya ringkasan kerangka pemikiran ini dapat dilihat pada gambar berikut:

Gambar 2.1

Kerangka Pikir Penelitian

\begin{tabular}{|c|c|}
\hline $\begin{array}{c}\text { KONDISI KEUANGAN } \\
\text { SEBELUM PENERAPAN } \\
\text { SISTEM ONLINE TAHUN 2007- } \\
\text { 2008 DILIHAT DARI : } \\
\text { OHC } \\
\text { BOPO }\end{array}$ & $\begin{array}{c}\text { KONDISI KEUANGAN } \\
\text { SESUDAH PENERAPAN SISTEM } \\
\text { ONLINE TAHUN 2009-2011 } \\
\text { DILIHAT DARI : } \\
\text { ROA }\end{array}$ \\
ODR & OHC \\
& BOPO \\
& ROA \\
\end{tabular}

\section{RESEARCH QUESTIONS}

Data yang digunakan adalah data kuantitatif yaitu data yang diukur dalam skala numerik (angka). Sumber data dari penelitian ini diperoleh dari data sekunder dan menggunakan sumber data internal yaitu data yang dikumpulkan oleh lembaga pengumpul data dan dipublikasikan kepada masyarakat pengguna data. Data sekunder berupa laporan keuangan tahunan Kospin Jasa periode 20072010 yang termuat pada laporan pengurus dan pengawas Kospin Jasa.

Populasi penelitian ini adalah Kospin Jasa sejumlah 30 kantor cabang. Pemilihan sampel dilakukan dengan metode purpose sampling dengan menetapkan kriteria sampel. Kriteria saham-saham yang akan dilakukan penelitian untuk dijadikan sampel penelitian adalah sebagai berikut: Kospin jasa yang mempunyai OHC, dan ROA positif selama periode amatan. Dari 30 Kospin jasa, diperoleh sampel sebanyak sebanyak 22 Kospin jasa. Penelitian diuji dengan menggunakan Uji beda paired sample t-test. 


\section{METHOD}

\subsection{Overhead Cost (OHC)}

OHC diukur dari Total Biaya dikurangi dengan biaya bunga, provisi, administrasi, penghapusan piutang, gathering dan bunga RAK (Rekening Antar Kantor) dibagi dengan Total Simpanan. Penerapan online membuat akses informasi menjadi mudah dan biaya overhead yang ditanggung perusahaan juga banyak yang terpangkas, sehingga adanya penerapan online mampu menurunkan biaya overhead. Manajer perlu mengoptimalkan sistem online, karena kelebihan sistem data online yang langsung dapat dilihat dan dirasakan adalah adanya penghematan dalam hal biaya atau cost, kemudian lebih cepat dan tepatnya aliran dan penerimaan informasi atau data, dan kemudian dapat dirasakan bahwa manajemen suatu organisasi atau perusahaan dapat lebih cepat dan tepat dalam hal pengambilan keputusan. Georgantopoulos dan Tsamis (2013) menunjukkan adanya perbedaan $\mathrm{OHC}$ sebelum sistem online dan sesudah sistem online.

H1: Ada perbedaan OHC antara sebelum penerapan sistem online tahun 20072008 dan sesudah penerapan sistem online dari tahun 2009-2010.

\subsection{BOPO}

BOPO diukur dari Biaya Operasional dibagi dengan Pendapatan Operasional. Rasio ini mencerminkan tingkat efisiensi perusahaan dalam menjalankan operasionalnya. Merupakan perbandingan dari biaya yang dikeluarkan oleh perusahaan dalam menjalankan aktivitas utamanya terhadap pendapatan yang diperoleh dari aktivitas tersebut. Aktivitas utama bank seperti biaya bunga, biaya tenaga kerja, biaya pemasaran dan biaya operasi lainnya, sedangkan pendapatan operasional adalah pendapatan bunga yang diperoleh dari penempatan dana dalam bentuk kredit dan pendapatan operasi lainnya. Semakin kecil rasio ini menunjukkan semakin efisien suatu perusahaan dalam menjalankan aktivitas usahanya.

Penerapan online, membuat biaya operasional yang ditanggung perusahaan banyak yang terpangkas, sehingga perusahaan lebih efisien dengan adanya penerapan online. Manajer perusahaan perlu mengerapkan sistem online ini dengan baik, dimana adanya penerapan sistem online membuat BOPO lebih efisien dari sebelum penerapan sistem online. Hays et al., (2012) menunjukkan adanya perbedaan BOPO sebelum sistem online dan sesudah sistem online. 
$\mathrm{H} 2$ : Ada perbedaan BOPO antara sebelum penerapan sistem online tahun 2007-2008 dan sesudah penerapan sistem online dari tahun 2009-2010.

\subsection{Return On Asset (ROA)}

Return On Total Assets diukur dari Sisa Hasil Usaha dibagi dengan Total Assets. ROA adalah rasio keuangan yang berhubungan dengan aspek earning atau profitabilitas. ROA berfungsi untuk mengukur efektifitas perusahaan dalam menghasilkan laba dengan memanfaatkan aktiva yang dimiliki. Semakin besar ROA yang dimiliki maka semakin efisien penggunaan aktiva sehingga akan memperbesar laba. Laba yang besar akan menarik investor karena perusahaan memiliki tingkat return yang tinggi. Rasio ini dapat dijadikan sebagai ukuran kesehatan keuangan. Rasio ini sangat penting, mengingat keuntungan yang diperoleh dari penggunaan aset dapat mencerminkan tingkat efisiensi usaha suatu bank dalam penggunaan asetnya yang sebagian besar adalah hutang.

Rasio profitabilitas (profitability ratio) terdiri atas dua jenis yaitu rasio yang menunjukkan profitabilitas dalam kaitannya dengan penjualan (profitabilitas penjualan) dan rasio yang menunjukkan profitabilitas dalam kaitannya dengan investasi (profitabilitas investasi). Rasio ini menjelaskan laba dari perusahaan yang berhubungan dengan penjualan, dikurangi biaya untuk memproduksi barang yang dijual. Rasio tersebut merupakan pengukur efisiensi operasi perusahaan, serta merupakan indikasi dari penetapan harga produk.

Margin laba bersih adalah ukuran profitabilitas perusahaan dari penjualan setelah memperhitungkan semua biaya dan pajak penghasilan. Margin tersebut menjelaskan penghasilan bersih perusahaan per rupiah penjualan. Dengan mempertimbangkan kedua rasio tersebut bersama-sama, diperoleh pandangan yang mendalam tentang operasi perusahaan. Jika margin laba kotor tidak terlalu banyak berubah sepanjang beberapa tahun, tetapi margin laba bersihnya menurun selama periode waktu yang sama, penyebabnya mungkin biaya penjualan, umum, dan administrasi yang terlalu tinggi dibandingkan dengan penjualannya, atau adanya tarif pajak yang lebih tinggi. Di pihak lain, jika margin laba kotor turun, biaya untuk memproduksi barang meningkat jika dibandingkan dengan penjualan. Kejadian ini bisa disebabkan oleh harga yang lebih rendah atau efisiensi operasi yang lebih rendah (Mocviociov, et al 2010).

Sekitar tahun 1919, Du Pont Company menggunakan pendekatan khusus untuk analisis rasio agar dapat mengevaluasi efektivitas perusahaan. Salah satu variasi dari pendekatan Du Pont memiliki relevansi khusus untuk memahami pengembalian atas investasi perusahaan. Ketika margin laba bersih dikalikan dengan perputaran total aktiva, diperoleh pengembalian atas investasi, atau daya untuk menghasilkan laba (earning power) atas total aktiva (Collier, et al 2010).

Baik margin laba bersih maupun rasio perputaran aktiva tidak dapat memberikan pengukuran yang memadai atas efektivitas keseluruhan jika berdiri sendiri. Margin laba bersih (NPM) tidak dapat memperhitungkan penggunaan aktiva, sementara rasio perputaran total aktiva (TATO) tidak memperhitungkan 
profitabilitas dalam penjualan. Rasio pengembalian atas investasi, atau daya untuk menghasilkan laba, mengatasi kedua kelemahan tersebut. Peningkatan dalam daya untuk menghasilkan laba perusahaan akan terjadi jika terdapat peningkatan dalam perputaran aktiva, peningkatan dalam margin laba bersih, atau keduanya. Dua perusahaan dengan margin laba bersih dan perputaran total aktiva yang berbeda, dapat saja memiliki daya untuk menghasilkan laba yang sama. Misalnya perusahaan $\mathrm{A}$, dengan margin laba bersih hanya 2 persen dan perputaran total aktiva 10, memiliki daya untuk menghasilkan laba yang sama yaitu 20, dengan perusahaan $\mathrm{B}$ yang memiliki margin laba bersih 20 persen dan rasio perputaran total aktiva 1. Bagi setiap perusahaan tersebut, setiap 100 dollar yang diinvestasikan dalam aktiva akan kembali 20 dollar laba setelah pajak per tahunnya (Van Horne; 2005).

Beberapa kasus besar di USA membuktikan bahwa perkembangan penjualan yang berlebihan dapat berakibat sebaliknya, bukan perkembangan atau laba yang makin besar tetapi permasalahan keuangan yang muncul. A firm can rapidly outgrow its cash supply and find itself in serious financial distress because of its success. Berdasarkan perkembangan terakhir, maka masalahnya bukan memacu penjualan, namun dengan berbagai tingkat penjualan berapa jumlah dana (kas) yang dibutuhkan, berasal dari mana, dan berapa beban yang layak untuk tambahan kas yang dibutuhkan ini. Konsep baru ini disebut dengan "aditional funds needed" atau AFN atau dana dari luar yang dibutuhkan.

Profitability adalah salah satu rasio rentabilitas yang terpenting digunakan untuk memprediksi harga atau return saham perusahaan publik. Profitability merupakan kemampuan perusahaan dalam menghasilkan laba dengan memanfaatkan asset yang dimilikinya. Rentabilitas merupakan rasio keuangan yang digunakan untuk analisis fundamental. Rasio-rasio keuangan yang digunakan untuk analisis fundamental dapat dikelompokkan dalam 5 jenis yaitu : rasio likuiditas, aktivitas, rentabilitas, solvabilitas dan rasio pasar (Brigham, 2005).

Menurut Weston dan Brigham (2004) seringkali hasil pengamatan menunjukkan bahwa perusahaan dengan tingkat pengembalian yang tinggi atas investasi menggunakan hutang yang relatif kecil. Meskipun tidak ada justifikasi teoritis akan hal ini, penjelasan praktis akan kenyataan ini adalah bahwa perusahaan yang sangat menguntungkan pada dasarnya tidak membutuhkan banyak pembiayaan dengan hutang. Laba yang ditahan perusahaan yang sangat tinggi sudah memenuhi untuk membiyai sebagaian besar kebutuhan pendanaan. Tahir et al., (2010) menunjukkan adanya perbedaan ROA sebelum sistem online dan sesudah sistem online.

H3: Ada perbedaan ROA antara sebelum penerapan sistem online tahun 20072008 dan sesudah penerapan sistem online dari tahun 2009-2010.

\subsection{Loan to Deposit Ratio (LDR)}

Loan To Total Deposits Ratio diukur dari Total Pinjaman dibagi dengan Total Simpanan. LDR merupakan rasio yang menunjukkan tingkat likuiditas suatu 
perusahaan, juga menunjukkan kemampuan dalam menjalankan fungsi intermediasinya dalam menyalurkan dana pihak ketiga ke kredit. Seperti halnya perusahaan secara umum, perusahaan juga mengukur rasio likuiditasnya, hanya saja bank tidak menggunakan acid test ratio ataupun current ratio tetapi menggunakan rasio LDR. Jika rasio ini menunjukkan angka yang rendah maka perusahaan dalam kondisi idle money atau kelebihan likuiditas yang akan menyebabkan perusahaan kehilangan kesempatan untuk memperoleh laba lebih besar. Tahir et al., (2010) menunjukkan adanya perbedaan LDR sebelum sistem online dan sesudah sistem online.

H4: Ada perbedaan LDR antara sebelum penerapan sistem online tahun 20072008 dan sesudah penerapan sistem online dari tahun 2009-2010.

\section{DISCUSSION}

Hasil penelitian ini menunjukkan adanya pengaruh yang signifikan dari $\mathrm{OHC}$ pada sebelum penerapan online dan sesudah penerapan online. Hasil penelitian ini menunjukkan $\mathrm{OHC}$ sesudah online lebih bagus daripada $\mathrm{OHC}$ sebelum online, hal tersebut dapat dilihat pada data rata-rata sebelum online sebesar 6,1264\% dan data sebelum online mempunyai rata-rata OHC lebih kecil yaitu sebesar 3,4977\%, maka dapat diidentifikasikan bahwa penerapan online, membuat akses informasi menjadi mudah dan biaya overhead yang ditanggung perusahaan juga banyak yang terpangkas, sehingga adanya penerapan online mampu menurunkan biaya overhead. Kelebihan sistem data online yang langsung dapat dilihat dan dirasakan adalah adanya penghematan dalam hal biaya atau cost, kemudian lebih cepat dan tepatnya aliran dan penerimaan informasi atau data, dan kemudian dapat dirasakan bahwa manajemen suatu organisasi atau perusahaan dapat lebih cepat dan tepat dalam hal pengambilan keputusan. Hasil penelitian ini mendukung teori signalling, dimana sinyal perusahaan yang positif dengan adanya penerapan sistem online membuat OHC lebih baik dari sebelum penerapan siste online. Hasil penelitian ini mendukung penelitian terdahulu yang dilakukan oleh: Georgantopoulos dan Tsamis (2013).

BOPO menunjukkan adanya perbedaan pada sebelum penerapan online dan sesudah penerapan online. Hasil penelitian ini menunjukkan BOPO sesudah online lebih bagus daripada BOPO sebelum online, hal tersebut dapat dilihat pada data rata-rata sebelum online sebesar $73,2186 \%$ dan data sebelum online mempunyai rata-rata BOPO lebih kecil yaitu sebesar 67,1591\%, maka dapat diidentifikasikan bahwa penerapan online, membuat biaya operasional yang ditanggung perusahaan banyak yang terpangkas, sehingga perusahaan lebih efisien dengan adanya penerapan online. Sistem data online dalam prakteknya menggunakan atau ditunjang oleh suatu alat atau piranti lunak. Alat penunjang sistem data online ini sering disebut sebagai software. Ada banyak software yang dipakai untuk mengimplementasikan sistem data online. Salah satu software yang 
paling digunakan oleh Kospin Jasa dalam mengimplementasikan sistem data online adalah software SysOn. Software SysOn inilah yang digunakan oleh Kospin jasa didalam mengimplementasikan sistem data onlinenya, dengan adanya sistem online ini maka terdapat penghematan dalam hal biaya atau cost. Hasil penelitian ini mendukung teori signalling, dimana sinyal perusahaan yang positif dengan adanya penerapan sistem online membuat BOPO lebih efisien dari sebelum penerapan sistem online. Hasil penelitian ini mendukung penelitian terdahulu yang dilakukan oleh: Hays et al., (2012).

ROA menunjukkan adanya perbedaan pada sebelum penerapan online dan sesudah penerapan online, dapat diidentifikasikan bahwa penerapan online, membuat perusahaan lebih mampu menghasilkan keuntungan dalam memanfaatkan aset yang dimilikinya. Hasil penelitian ini menunjukkan ROA sesudah online lebih bagus daripada ROA sebelum online, hal tersebut dapat dilihat pada data rata-rata sebelum online sebesar $5,0261 \%$ dan data sebelum online mempunyai rata-rata ROA lebih besar yaitu sebesar 5,6595\%, SysOn mampu membuat Kospin Jasa lebih optimal dan efisien, tetapi juga memberikan add value yang dibutuhkan bagi Kospin Jasa untuk berkembang dan eksis didalam dunia persaingan lembaga keuangan yang ketat. Hasil penelitian ini mendukung teori signalling, dimana sinyal perusahaan yang positif dengan adanya penerapan sistem online membuat ROA lebih besar dari sebelum penerapan sistem online. Hasil penelitian ini mendukung penelitian terdahulu yang dilakukan oleh: Tahir et al., (2010).

LDR menunjukkan adanya perbedaan pada sebelum penerapan online dan sesudah penerapan online, maka dapat diidentifikasikan bahwa penerapan online, membuat perusahaan kurang mampu dalam memasarkan dananya, hal ini dikarenakan perusahaan lebih berhati-hati dalam menempatkan dananya kedalam aktivitas investasi yang menguntungkan. Hasil penelitian ini menunjukkan LDR sesudah online lebih bagus daripada LDR sebelum online, hal tersebut dapat dilihat pada data rata-rata sebelum online sebesar $95,5391 \%$ dan data sebelum online mempunyai rata-rata LDR lebih kecil yaitu sebesar 64,1907\%, SysOn merupakan suatu solusi core Kospin Jasa Sistem bersifat customisable yang dapat disesuaikan dengan kebutuhan Kospin Jasa terutama yang terkait dengan perubahan proses bisnis yang bersumber pada perubahan regulasi, ketentuan, maupun kebijakan lainnya. Hasil penelitian ini mendukung teori signalling, dimana sinyal perusahaan yang positif dengan adanya penerapan sistem online membuat LDR lebih baik dari sebelum penerapan sistem online. Hasil penelitian ini mendukung penelitian terdahulu yang dilakukan oleh: Tahir et al., (2010).

\section{CONCLUSIONS}

\subsection{Simpulan}


Berdasarkan analisis yang dilakukan terhadap hipotesis yang dirumuskan, maka dapat diambil kesimpulan sebagai berikut:

1. Dari pengujian hipotesis pertama, menunjukkan bahwa perbedaan sebelum penerapan online dan sesudah penerapan online menunjukkan nilai t sebesar 7,638 dengan signifikansi sebesar 0,000 Nilai signifikansi di bawah 0,05 menunjukkan adanya perbedaan $\mathrm{OHC}$ yang signifikan. Hal ini berarti Hipotesis 1 diterima.

2. Berdasarkan hipotesis kedua menunjukkan bahwa hasil pengujian perbedaan sebelum penerapan online dan sesudah penerapan online menunjukkan nilai $t$ sebesar 5,413 dengan signifikansi sebesar 0,000 Nilai signifikansi di bawah 0,05 menunjukkan adanya perbedaan BOPO yang signifikan. Hal ini berarti Hipotesis 2 diterima.

3. Berdasarkan hipotesis ketiga menunjukkan bahwa hasil pengujian perbedaan sebelum penerapan online dan sesudah penerapan online menunjukkan nilai t sebesar -2,645 dengan signifikansi sebesar 0,011 Nilai signifikansi di bawah 0,05 menunjukkan adanya perbedaan ROA yang signifikan. Hal ini berarti Hipotesis 3 diterima.

4. Berdasarkan hipotesis keempat menunjukkan bahwa hasil pengujian perbedaan sebelum penerapan online dan sesudah penerapan online menunjukkan nilai t sebesar -4,527 dengan signifikansi sebesar 0,000 Nilai signifikansi di bawah 0,05 menunjukkan adanya perbedaan LDR yang signifikan. Hal ini berarti Hipotesis 4 diterima.

\subsection{Saran}

Saran yang dapat diberikan dari hasil penelitian ini bagi Kospin Jasa adalah sebagai berikut:

1. Manajer Kospin Jasa perlu menekan biaya overhead, dimana penerapan online membuat akses informasi menjadi mudah dan biaya overhead yang ditanggung perusahaan juga banyak yang terpangkas, sehingga adanya penerapan online mampu menurunkan biaya overhead. Manajer perlu mengoptimalkan sistem online, karena kelebihan sistem data online yang langsung dapat dilihat dan dirasakan adalah adanya penghematan dalam hal biaya atau cost, kemudian lebih cepat dan tepatnya aliran dan penerimaan informasi atau data, dan kemudian dapat dirasakan bahwa manajemen Kospin Jasa dapat lebih cepat dan tepat dalam hal pengambilan keputusan

2. Manajer Kospin Jasa perlu menekan biaya operasional, dimana penerapan online, membuat biaya operasional yang ditanggung perusahaan banyak yang terpangkas, sehingga perusahaan lebih efisien dengan adanya penerapan online. Manajer perusahaan perlu mengerapkan sistem online ini dengan baik, dimana adanya penerapan sistem online membuat BOPO lebih efisien dari sebelum penerapan sistem online.

3. Manajer Kospin Jasa perlu meningkatkan ROA, penerapan online, membuat perusahaan lebih mampu menghasilkan keuntungan dalam memanfaatkan 
aset yang dimilikinya. Manajer perlu mengoptimalkan keuntungan yang tinggi melalui pemanfaatan aset yang baik, SysOn mampu membuat Kospin Jasa lebih optimal dan efisien, tetapi juga memberikan add value yang dibutuhkan bagi Kospin Jasa untuk berkembang dan eksis didalam dunia persaingan lembaga keuangan yang ketat.

4. Manajer Kospin Jasa perlu meningkatkan LDR, penerapan online, perlu menyalurkan dana agar LDR meningkat dan dapat mengurangi iddle money. SysOn merupakan suatu solusi core Kospin Jasa Sistem bersifat customisable yang dapat disesuaikan dengan kebutuhan Kospin Jasa terutama yang terkait dengan perubahan proses bisnis yang bersumber pada perubahan regulasi akan menarik minat debitur untuk menggunakan jasa Kospin Jasa, hal lain bisa dapat dilakukan adalah dengan memberikan reward bagi anggota yang bersedia untuk mereferensikan.

\section{REFERENCES}

Anggaran Dasar dan Anggaran Rumah Tangga Kospin Jasa, 2006.

Brigham, F Eugene, (2005) "Fundamental of financial Management," The Dryden Press: Holt-Sounders Japan,Third Edition

Brigham dan Houston, (2004), "Manajemen Keuangan," Edisi Kedelapan, Penerbit Erlangga

Collier, Michael, Shaer Biabani; dan Mohammad Thaleghani, (2010), "The effect of industry on the relation between capital structure and profitability of Tehran stock exchange firms," Journal of Basic and Applied Scientific Research

Dahlan Siamat, (1995) Manajemen Bank Umum, Inter Media - Yakarta

Farid Harianto dan Siswanto Sudomo, (1998), Perangkat dan Teknik Analisis Investasi di Pasar Modal Indonesia, PT. Bursa Efek Jakarta, Jakarta.

Furts, Lang, Nolle (2000), Internet Banking : Development and Prospests, Economic and Policy Analysis Working Paper

Georgantopoulos, Andreas G dan Anastasios D Tsamis, (2013), "Assesing the eficiency of commercial bank in Greece during the financial crisis," Journal of Money, Investment and Banking

Gujarati, DN, (1995), “Basic econometrics,” Singapore: Mc Graw Hill, Inc

Hays, Fred H; Stephen A De Lurgio; dan Arthur H Gilbert, (2012), "Efficiency ratios and community bank performance," Journal of Finance and Accoutancy

Ikatan Akuntan Indonesia. 2002. Standar Akuntansi Keuangan. Jakarta. Penerbit : Salemba Empat. 
Imam Ghozali, 2004, "Aplikasi Analisis Multivariate dengan program SPSS," Badan Penerbit UNDIP, Semarang

Laporan Rapat Anggota Tahunan Kospin Jasa 2007, 2008, 2009, 2010 dan 2011, Kospin Jasa

Maholtra, Pooja dan Singh Balwinder, 2006, Impact of Internet Banking on Bank's Performance : The Indian Experience, The Asian Journal of Management

Mocviociov, Julija, Olga Kolyanev, dan Victor Kapanov, (2010), "The determinants of profitability in the Baltic states and Rusia," Electronic Publications of Pan European Institutes

Modul Training Sistem Online Kospin Jasa Tahun 2008, Counterpart Kospin Jasa

Peraturan Menteri Negara Koperasi dan Usaha Kecil dan Menengah Republik Indonesia Nomor : 20/Per/M/KUKM/XI/2008 Tahun 2008, tentang Pedoman Penilaian Kesehatan Koperasi Simpan Pinjam dan Unit Simpan Pinjam Koperasi.

Peraturan pemerintah Nomor 9 Tahun 1995 tentang Pelaksanaan Kegiatan Usaha Simpan Pinjam

Reza Kurniawan, 2002, Analisis Kinerja Perbankan Sebelum dan Setelah Penerapan Internet Banking, Jurnal Universitas Widyatama

Suad Husnan, (1998), “Manajemen Keuangan-Teori dan Penerapan (Keputusan Jangka Panjang)," Buku I, Edisi 4, BPFE

Tahir, Izah Mohd; Nor Mazlina Abu bakar; dan Sudin Haron, (2010), "Cost and profit efficiency of the Malaysian commercial banks," International Journal of Economics and Finance

Tim Ikopin. 2000. Penjiwaan Koperasi. Bandung : Ikopin. Jatinangor, Bandung : Ikopin

Weston, J.F. dan Copland, T.E. (1997), “Manajemen pendanaan,” Edisi 7. Jakarta : Penerbit Bina Rupa Aksara

Van Horne, J.C (2005), "Financial Management and Policy," Edisi 10, New York, Prentice-Hall

Zakky Arslan Djunaid, dkk, 2008, Berpikir Besar Dalam Koperasi, PT. Perintis Jasa Grafika, Pekalongan. 